\title{
Heparin-like inhibitor, not vitamin-K deficiency in the newborn
}

Citation for published version (APA):

van Doorm, J. M., Muller, A. D., \& Hemker, H. C. (1977). Heparin-like inhibitor, not vitamin-K deficiency in the newborn. Lancet, 309(8016), 852-853. https://doi.org/10.1016/S0140-6736(77)92795-7

Document status and date:

Published: 16/04/1977

DOI:

10.1016/S0140-6736(77)92795-7

Document Version:

Publisher's PDF, also known as Version of record

\section{Please check the document version of this publication:}

- A submitted manuscript is the version of the article upon submission and before peer-review. There can be important differences between the submitted version and the official published version of record.

People interested in the research are advised to contact the author for the final version of the publication, or visit the DOI to the publisher's website.

- The final author version and the galley proof are versions of the publication after peer review.

- The final published version features the final layout of the paper including the volume, issue and page numbers.

Link to publication

\footnotetext{
General rights rights.

- You may freely distribute the URL identifying the publication in the public portal. please follow below link for the End User Agreement:

www.umlib.nl/taverne-license

Take down policy

If you believe that this document breaches copyright please contact us at:

repository@maastrichtuniversity.nl

providing details and we will investigate your claim.
}

Copyright and moral rights for the publications made accessible in the public portal are retained by the authors and/or other copyright owners and it is a condition of accessing publications that users recognise and abide by the legal requirements associated with these

- Users may download and print one copy of any publication from the public portal for the purpose of private study or research.

- You may not further distribute the material or use it for any profit-making activity or commercial gain

If the publication is distributed under the terms of Article $25 \mathrm{fa}$ of the Dutch Copyright Act, indicated by the "Taverne" license above, 


\section{Letters to the Editor}

\section{RESEARCH ON INFANTS}

SiR,-Dr Pratt (March 26, p. 699) asks for "guidelines about the circumstances in which it is legally permissible and ethically acceptable to take blood from minors (particularly babies) purely for purposes of research". This important question was the subject of an editorial in Archives of Disease in Childhood, ${ }^{1}$ which Dr Pratt may find goes some way to providing what she seeks. The following points were there made.

(1.) The Medical Research Council's statement of $1963 \mathrm{im}$ plying that such blood-sampling would be illegal cannot be accepted as giving an incontrovertible opinion on how the law now stands; a contrary interpretation was reached by Curran and Beecher, ${ }^{2}$ for instance. The matter remains open, having never been tested in the courts.

(2.) A value judgment is involved. Is the potential gain in medical knowledge commensurate with possible discomfort or pain to the baby? The same principle should be applied whether the investigation involves trivial interference with the baby - e.g., weighing it more often than usual-or less trivial, as with blood-sampling.

(3.) Such value judgment is best made by a local ethical research committee.

Dr Prate's local ethical committee member who told her that the committee would regard blood-sampling from children for research as not legally permissible, was presumably merely citing the M.R.C.'s questionable opinion. She need not have left the matter there: she should have put her original research proposals to the ethical committee, accompanied by copies of the editorial referred to or the admirable article by Campbell on the same subject.

17 Ruthertord Road,

Cambridge $\mathrm{CB} 22 \mathrm{HH}$

DOUGLAS GAIRDNER

SIR,-Dr Pratt has raised the question of blood-sampling in infants where the investigation seems to be of no direct benefit to the babies. Like many others, she has found it difficult to persuade her local ethical research committee that the informed consent of parents is sufficient to allow her to carry out such research investigations on infants.

It is time that some clear lead was given to prediatric investigators in this important matter. The law, as interpreted by the Medical Research Council, seems to be that such procedures are illegal. While it is clear that some safeguards are needed, it is logically indefensible to adopt the position that normal individuals (of whatever age) are not proper subjects for investigation. If this were the case then it would be unethical to investigate the sick person because we would have no standards to which to relate our data, which would thus be made meaningless. The question, then, is the degree to which interference with the healthy person is permissible. In the view of the M.R.C. and the Medical Defence Union this apparently stops short of venepuncture and fingerprick.

Why these procedures should be unethical, whereas measurement of height, weight, head circumference, and components of urine, being less invasive, are presumably permitted, is not immediately apparent. One could argue that they involve greater risk and greater pain to the subject. There are indeed risks of both venepuncture and capillary blood-sampling - hrmatomas may be produced, which may become infected; excessive hamorrhage may occur; arteriovenous aneurysms, air emboli, and osteomyelitis have been described. Serious complications of this kind are very rare. The fact that they may be sequelæe of a procedure which was not strictly necessary for the well being of a particular child does not make that procedure unethical so long as the untoward complication remains a remote possibility. Otherwise it would be immoral to take a young child on a motorcar journey which was not specifically for his benefit: the risks of his being involved in a roadtraffic accident would be too great.

The second reason for banning such investigations on children might be on the grounds of the pain involved. We submit that if the parents would give consent for needle puncture upon themselves, as part of a research investigation, then it is perfectly reasonable for them to give such consent on behalf of their child. We have no reason to suppose that infants are less altruistic than their parents. From their point of view, they are, for admirable reasons, subjected to the pain of vaccination, but they have no more understanding of the worthy motives behind this painful procedure than of the equally well motivated objectives of medical research. It is our experience that children, by the time they are 10 years of age, are not only able to understand but are also usually very willing to participate in such research procedures. It is paradoxical that a society which allows parents considerable individual freedom to negiect or ill-treat their children, denies those same parents the right to involve their children in medical research designed to alleviate human suffering.

Department of Child Health, Welsh National School of Medicine, Cardiff CF4 4XN

JOHN A DODGE JoHn Evans

\section{IUEPARIN-LIKE INHIBITOR, NOT VITAMIN-X DEFICIENCY, IN THE NEWBORN}

Sir, - Vitamin-K deficiency in man causes normal prothrombin to decrease, and abnormal prothrombin to appear in the blood. ${ }^{1}$ We checked for vitamin-K deficiency in the newborn by testing for abnormal prothrombin. In 43 healthy babies a $20 \mathrm{~cm}$ piece of umbilical cord was clamped directly after birth. $9 \mathrm{ml}$ of blood was withdrawn by puncture from the umbilical vein into a polypropylene syringe with $1 \mathrm{ml}$ of a solution containing hydroxyethylpiperazine-ethanesulphuric acid (hepes) $0.3 \mathrm{mo} / /$, trisodium citrate $0.1 \mathrm{mo} / \mathrm{h}$, sodium azide 15 $\mathrm{mmol} / \mathrm{l}$ and aprotinin ('Trasylol') $15 \mathrm{mmol} / \mathrm{h}$, at $\mathrm{pH} \mathrm{7.3.} \mathrm{This}$ mixture prevents fibrino(geno)lysis. Plasma was obtained by centrifugation and made platelet poor by a second centrifugation for $30 \mathrm{~min}$ at $4^{\circ} \mathrm{C}$ and $20000 \mathrm{~g}$. It was frozen in $1 \mathrm{ml}$ volumes and stored at $-20^{\circ} \mathrm{C}$. In these plasmas we estimated ${ }^{2}$ the clotting factors prothrombin and factors $\mathrm{v}, \mathrm{vil}$, and $\mathrm{x}$ by a one-stage procedure and prothrombin also by a two-stage procedure.

Abnormal prothrombin (or protein induced by vitamin- $K$ absence analogous to factor II [P.I.V.K.A.-H] ) is a precursor of normal prothrombin that in a vitamin-K-dependent process has ten glutamic (Glu) residues converted into $x$-COOH glutamic acid (Gla) residues. ${ }^{1-3}$ The Gla residues are essential for the normal generation of thrombin from prothrombin by the physiological activator prothrombinase." P.I.V.K.A.-H does contain normal thrombin and will generate thrombin activity normally with non-physiological activators such as staphylocoagulase and Echis carinatus venom. ${ }^{2-0}$ P.I.V.K.A.-11 shows complete immunological identity with prothrombin and is estimated with prothrombin in one-dimensional crossed immunoelectro-

1. Hemker, H. C., Veltkamp, J. J., Hensen, A., Loeliger, E. A. Nature, 1965 200,589

2. Bas, B. M., Muller, A. D., van der Voort-Beelen, J. M. 9. mol. Med. 1975 1,65 .

3. Stenflo, J., Fernlund, P., Egan, W., Roepstorf, P. Proc, natr. Acad. Sci. U.S.A. 1974, 71, 2730.

4. Nelsestuen, G. L., Zytkovicz, T. H., Howard, J. B. Mayo Clin. Proc. 1974 49,941 .

5. Esmon, Ch. T., Suttic, J. W., Jackson, C. M. F. biol. Chem. 1976, 250, 4095.

6. Hemker, H. C., Bas, B. M., Muller, A. D. Biochim. biophys. Acta, 1975 , 379,180 . 
DETERMINATION OF CLOTTING FACTORS IN CORD BLOOD

\begin{tabular}{l|l|c}
\hline Factor & \multicolumn{1}{|c|}{ Method } & Concentration* \\
\hline II & One stage & $49 \pm 11$ \\
II & Two stage & $47 \pm 10$ \\
II & E. carinatus venom & $51 \pm 10$ \\
II & Staphylocoagulase & $48 \pm 8$ \\
II & C.I.E. & $51 \pm 11$ \\
v & One stage & $60 \pm 11$ \\
vII & One stage & $43 \pm 11$ \\
X & One stage & $33 \pm 13$ \\
Antithrombin III & C.I.E. & $57 \pm 12$ \\
$\alpha_{1}$-antitrypsin & C.I.E. & $77 \pm 15$ \\
$\alpha_{2}$-macroglobulin & C.I.E. & $105 \pm 19$ \\
\hline
\end{tabular}

* Mean \pm S.D. of levels in 43 newborns as percentage of pooled blood from 30 healthy adults.

phoresis (C.I.E.). The table shows that the amount of factor II found in those tests where P.I.V.K.A.-1I will be coestimated is equal to the amount found in the one-stage test. Hence no P.I.V.K.A. $\mathrm{n}$ is demonstrated in this way.

P.I.V.K.A.-II will show up in a two-dimensional C.I.E. when calcium ions ( $2 \mathrm{mmol} / \mathrm{l}$ calcium lactate) are present in the firstdimension run. This is because Gla residues bind calcium ions and slow the electrophoretic mobility of prothrombin relative to that of the Glu-containing P.I.Y.K.A.-11. No P.I.V.K.A.-11. could be demonstrated in the newborn in this way either.

The plasma of the newborn, therefore, does not contain P.I.V.K.A.-II and we conclude that healthy babies, contrary to current belief's, are not likely to have vitamin-K deficiency.

During these investigations we found, in 25 out of the 43 plasmas, a hitherto unrecognised heparin-like inhibitor. ${ }^{7}$ The role of this inhibitor in health and disease still has to be elucidated. Anyway, the coagulation status of the newborn resembles that of parenteral anticoagulation (heparin) more closely than that of oral coagulation (dicoumarol). Administration of vitamin $\mathrm{K}$ to the newborn is not supported by our findings. For generalised bleeding complications in the newborn protamin chloride should be considered.

Department of Obstetrics and Gynæcology, Onze Lieve Vrouwen Gasthuis, Amsterdain, Netherlands

J. M. VAN DOORM

Department of Biochemistry,

Biomedical Centre

State University Limburg

Maastricht, Netherlands

A. D. MULLER

H. C. HeMKER

\section{ORAL TREATMENT OF CARNITINE MYOPATHY}

Sir,--Inborn errors of carnitine metabolism have been successfully treated with oral supplements of $\mathrm{D}, \mathrm{L}$-carnitine. ${ }^{1-4}$ We have tried this treatment in a boy with carnitine myopathy; the clinical and biochemical findings were described in 1975.

Before diagnosis, the patient had been given vitamin-B complex without benefit. A low-fat/high-carbohydrate diet was tried, medium-chain triglycerides having proved too nauseating. With this there was some improvement and decrease in nausea, but the patient remained very weak. With the introduction of $1.5 \mathrm{~g} /$ day of $\mathrm{D}, \mathrm{L}$-carnitine his muscle power and performance improved. At first higher doses of carnitine exacerbated his vomiting, but after four months he was able to tolerate $2.5 \mathrm{~g} /$ day and after seventeen months the daily intake,

7. Muller, A. D., van Doorm, J. M., Fenker, H. C. Nature (in the press).

1. Engel, A. G., Angelini, C., Nelson, R. A. in Pxploratory Concepts in Muscular Dystrophy 11 (edited by A. T. Milhorat); p. 601, Amsterdam, 1974.

2. Karpati, G., Carpenter, S., Engel, A. G., Watters, G., Allen, J., Rothman, S., Klassen, G., Mammer, O. A. Neurology, Minneapolis, 1975, 25, 16. 3. Angelini, C. ibid. 1976, 26, 633 .

4. Angelini, C., Lucke, S., Canatarutti, F. ibid.

5. Smyth, D. P. L., Lake, B. D., MacDermot, J., Wilson, J. Lancet, 1975, i, 1198.
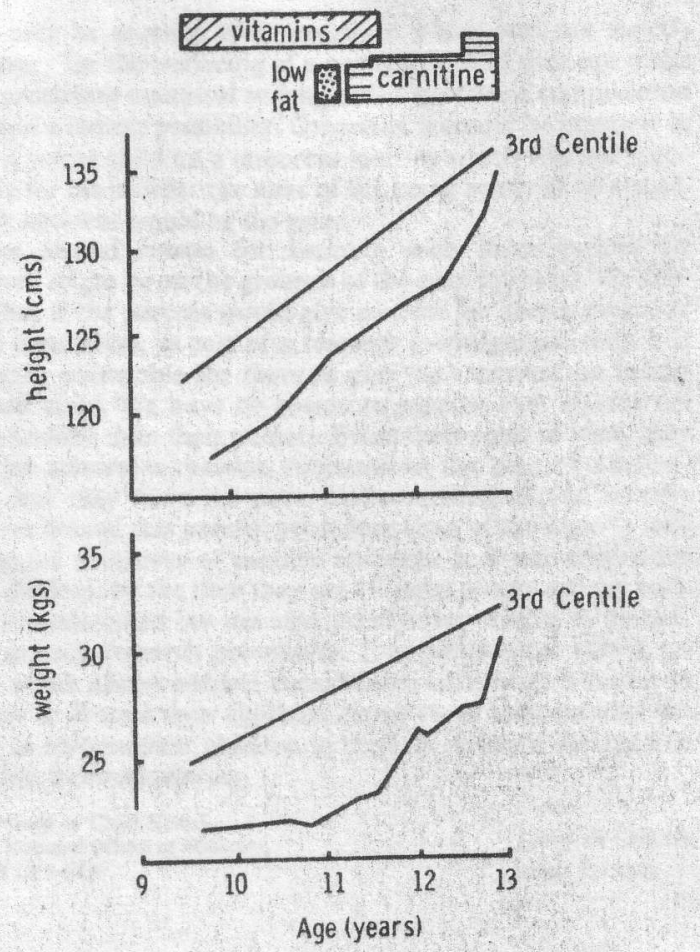

Effect of oral carnitine on growth-rate of a boy with carnitine myopathy.

in three divided doses, was increased to $4 \mathrm{~g}$. Throughout the time this boy has been receiving $\mathrm{D}, \mathrm{L}$-carnitine, his muscle strength has steadily improved and he is no longer troubled with nausea and vomiting. We have been further impressed, particularly after the latest increase in the dose of $\mathrm{D}, \mathrm{L}$-carnitine, by the much improved growth-rate (see figure).

Our experience, therefore, confirms the value of oral carnitine in the treatment of an otherwise severely incapacitating progressive disease.

Department of Neurology, Hospital for Sick Children, London WC1N $3 \mathrm{JH}$
G. P. Hosking

N. P. C. Cavanagh

D. P. L. SMYTH

J. WiLSON

\section{PHENYLALANINE HYDROXYLASE IN MUMAN PLACENTA: NOVEL SYSTEM FOR STUDY OF PHENYLKETONURIA}

SIR,-Hoffbauer and Schrempf ${ }^{1}$ have described the activity of phenylalanine hydroxylase in cultured human skin fibroblasts. We would like to report the presence of a high level of activity of phenylalanine hydroxylase in human term placenta.

Fresh term placentas were obtained within minutes of delivery. Thin slices $1-3 \mathrm{~mm}$ in size and of $1-2 \mathrm{~g}$ wet weight were prepared from each placenta. The placental fragments were washed three times with cold $0.15 \mathrm{~mol} / 1$ sodium chloride solution and then incubated with $1 \mathrm{ml}$ of tissue culture medium 199 without serum to which 550000 counts/min (1490 pmol) of purified $\mathrm{L}^{-14} \mathrm{C}$-phenylalanine was added. The fragments were incubated at $37^{\circ} \mathrm{C}$ for $4 \mathrm{~b}$, and culture was terminated by the addition of hydrochloric acid to a final concentration of $6 \mathrm{~mol} / \mathrm{l}$. The entire reaction mixture was hydrolysed for $20 \mathrm{~h}$ at $100^{\circ} \mathrm{C}$. After this hydrolysis the hydrochloric acid was evaporated and samples of each reaction were chromatographed

1. Hoffbauer, R. W., Schrempt, G. Lancet, 1976, i, 194. 